\title{
DEBIUTY
}

\section{EDUCATIONAL ACTIVITY OF SENIORS IN POLISH LITERATURE IN RECENT YEARS AND THE STUDENTS' OPINION}

\begin{abstract}
The phenomenon of population ageing is important for the state not only for business, economic or demographic reasons, but also for social aspects. A broadly defined pedagogy of ageing is important for the development of seniors, but also for changes in the awareness of society which starts to recognise the significant influence that elderly people have for the functioning of the state. The article refers to the issue of educational activity of elderly people and its role in improving their quality of life. The education of senior citizens is one of the opportunities for developing cooperation between younger population groups and the elderly. Therefore, in addition to the Polish literature on active ageing, the article will also include the collected opinions of students, which reflect the considerations of the contemporary generation regarding the discussed issue.
\end{abstract}

Keywords: old age, elderly people, elderly activity, educational activity of seniors, University of the Third Age.

\section{Introduction}

Increasing life expectancy is an undeniable achievement of civilisation, but at the same time it creates a number of challenges in each sphere of state functioning: political, economic, civic, educational, cultural and social. Old age is an inevitable stage in everyone's life, and trying to define it holistically is not an easy task. The social sciences, humanities, economics or biology have been studying the complexity of this phenomenon for years. Each field provides new knowledge and viewpoints,

\footnotetext{
* Aneta Żmijewska, Cardinal Stefan Wyszyński University in Warsaw, Faculty of Education, Doctoral School; e-mail: anetazmijewska@op.pl.
} 
as well as raises issues for further reflection and discussion on aspects related to old age and population ageing. At this point, it is also necessary to emphasise the difference between the concepts of old age and aging, since the former is defined as a phase of a person's life, while the latter is determined as a process (Szarota 2004). The need to address the issue of old age has also emerged in the pedagogical sciences. Referring to Aleksander Kamiński, pedagogy is not a science that deals only with the education of children, but its purpose and main idea is to educate people at every stage of their lives. The phenomenon of old age and ageing in educational science is developed mainly in social pedagogy, special education, andragogy, or care services pedagogy. These areas are primarily concerned with the education of elderly persons in the broadest sense, which should be understood as supporting their development (Leszczyńska- Rejchert 2006). The topic of this article concerns the concept of senior education as a form of activity of the elderly in the modern world and the presentation of the students' perspective on the discussed issue. Are the stereotypical views and evaluations commonly accepted by the young generation reflected in the opinion of students at Cardinal Stefan Wyszynski University? Presenting students' opinions is essential since education in old age should not only refer to seniors. Gerontological education should concern all social groups and be implemented in many areas, which would facilitate the process of intergenerational cooperation and mutual assistance (Eopatkowa 2005). One course of action should be to extend the educational process to seniors themselves, preparing them for old age, and the other should be to educate younger generations. Such multifaceted educational activities, according to Zofia Szarota, „[...] may contribute in the future to changing the social, still unfortunately negative, image of old age. They can form positive habits that contribute to physical and mental as well as economic well-being of individual and social ageing" (Szarota 2002, p. 141)

\section{Activity of seniors in literature in recent years}

One of the most common opinions describing old age as a period filled with problems, difficulties or barriers in everyday life is based on negative stereotypes commonly functioning in the Polish society. Jerzy Piotrowski noticed in the ,70s that the social stereotype of the elderly is one of the factors of perceiving the aging of the society as a disaster (Piotrowski 1973). Negative stereotypes can be constructed in various areas, including: biological (through the prism of physical features), mental (through the prism of adaptive or cognitive systems) and social (through the prism of changes in activity, lifestyle or social roles) (Tomaszewska-Hołub 2019). The predominance of negative stereotypes over positive ones is confirmed by numerous empirical studies (Leszczyńska-Rejchert 2019; Nawrocka 2013; Kurcz 2001). One of the most frequent views towards seniors are „[...] those about their disability, asexuality, negative approach to life and people, passivity, aversion, isolation, conservatism” (Hebda, Biela 2015, p. 55). „There is also a widespread belief that elderly 
people do not use the Internet because they do not want and are unable to learn how to use the computer and the Internet" (Bąk, Hołda 2013, p. 133). Nowadays, seniors are also shown as ,dependent people, in a bad economic situation and poor health condition, struggling with family problems, often infirm, requiring constant help, care and support" (Tomaszewska-Hołub 2019, p. 94).

It is a fact that the above-mentioned issues occur and may even worsen in old age. They are not the only concepts with which old age can be described, yet they are among the most frequently used terms in describing the time of old age. Stigmatizing can also be observed, which is related to the top-down assignment of social roles and tasks are defined as those „most appropriate” for seniors. In Poland, there is still an ,appropriate” model of a senior who looks after their grandchildren, devotes themselves to helping the family, take care of the garden plot and spend time in the church, and "has to give up many things, including pleasure, work" (Hebda, Biela 2015, p. 58). However, it is only a part of life of elderly people. Ageing is a naturally occurring process in people's lives that is increasingly associated with adopting socially active attitudes, taking advantage of local opportunities and engaging in social and community life. In the literature, active ageing is broadly defined as active participation in family, community, cultural, social and intellectual life. Activity and development are natural human needs, and their absence is associated with a disrupted relationship with the world and with other people (Miszczak 2010). In old age, the attitude of active functioning is not only „[...] praised, but even portrayed as necessary for a fulfilling lifestyle. With the various disadvantages that come with advancing years of life, activity in its broadest sense can become a way of mitigating the negative effects of ageing and highlighting benefits that come with ageing" (Miszczak 2010, p. 27).

The perception of activities meant for people over 65 can be multi-faceted. For elderly people, these are all activities aimed at addressing needs, promoting physical and mental well-being, counteracting social exclusion and loneliness, and enabling them to develop and enjoy life "to the full". An important aspect of senior education is adapting to the modern world and coping with the new reality (Chabior i in. 2014).

A wide range of activities can be found in the literature. Grażyna Orzechowska lists the following types of activities carried out in old age:

1. home and family activities;

2. professional activity;

3. social activity;

4. educational activity;

5. cultural activities;

6. religious activity;

7. recreational activity (Orzechowska 1999).

The categories of activity mentioned above cover almost all areas of a person's life. Most of the activities described earlier should be pursued in order for an older 
person to continue enjoying their life. Of course, not all of them have to be present in everyday life. The choice of activities will not only depend on the health condition, family situation and personal preferences, but will also reflect the social context as well as the expectations and propositions of the social environment in which the elderly person lives (Steuden 2011). Stanisława Steuden believes that the activity of the elderly people „works on the principle of feedback - it is an expression of a positive response to the tasks associated with this period, and at the same time, by strengthening self-esteem, it becomes a driving force for further development" (Steuden 2011, p. 82).

One of the most important activities in the life of an elderly person is activity in the home environment. A full or simply „sufficient” level of fitness is a quality that enables independence, as well as autonomy and control over one's own life. Activities of daily living include not only those related to housework, but also those related to personal fitness and hygiene, as well as mobility. Barbara Bień includes washing or getting dressed in the concept of personal fitness and hygiene. On the other hand, mobility is connected with going outside, negotiating stairs or moving around the apartment. It is in these groups of activities of daily living that a large amount of activity is so important in order to maintain a high level of fitness thanks to which one can pursue cultural or recreational activities (Bień 2002).

Professional activity is another area that combines multiple aspects to maintain a satisfactory standard of living for the elderly people. Paid work not only allows a person to maintain a similar financial level to that of their working age but, more importantly, it allows a person to continue socialising. Not only in Poland, but in many countries around the world, the data clearly show that people over 65 , in the vast majority, are not economically active. Information contained in the latest report "Situation of elderly people in Poland in 2018” created by the Central Statistical Office, shows that $86 \%$ of all elderly people were professionally inactive in 2018 , and this number increased by $2.5 \%$ compared to 2017 . The percentage of professionally inactive persons in 2018 was $92 \%$ for women aged 60 and $77.6 \%$ for men in the same age group. Although paid work past a certain retirement age is not often undertaken, a positive change in society's perception of elderly people in the labour market is evident. Increasingly, both employers and colleagues value the ,contribution' that elderly people make to company business operations. The knowledge and experience of long-term employees, who have been refining their professional skills for decades, is recognised. According to the data of the Central Statistical Office in the aforementioned report, almost $7.5 \%$ of all professionally active Poles are seniors. (Central Statistical Office 2020) ${ }^{1}$.

1 The presented data from the report „Situation of elderly people in Poland in 2018” of the Central Statistical Office are the most recently available data. 


\section{Educational activity of seniors}

The literature relating to ageing and old age (Dubas 2010; Dzięgielewska 2006, 2008; Demetrio 2006; Trafiałek 2000) points to the particular importance of education for seniors especially in today's world. „[...] there seems to be no doubt today that the current need of a modern person to find himself/herself in the reality which "attacks" him/her, makes learning a continuous, inseparable process, which must become a permanent element of personality functioning" (Semków 2007, p. 36). It is necessary to realise that a person is a being whose development, in its broadest sense, is an ongoing process that takes place at every stage of an individual's life; therefore, the desire to improve oneself and to educate in general is natural in elderly people. „From a social development perspective, learning in old age provides the necessary competences for full participation in human relations, the media, politics or the local community. From the point of view of personal development, learning not only allows knowledge or skills to be acquired and updated, but also becomes a tool for achieving full development" (Fabiś i in. 2015, p. 172). There will be more and more active senior citizens, especially those interested in the area of personal development and further education. They will use educational services and participate in non-formal education with greater ease.

Education in old age is not only a way of acquiring new skills, but above all a chance to learn about oneself and adapt to a new reality as well as improve one's quality of life (Halicki 2009). Przemysław Ziółkowski lists 5 main functions that educational activity for elderly people fulfils:

- educating (develops and improves dispositions);

- adaptive (adapts to the new social situation);

- compensatory (compensates for deficiencies in various areas);

- integrative (adapts to functioning in a new social group);

- psycho-hygienic (raises authority, allows to feel satisfaction) (Ziółkowski 2017).

Education is therefore a form of activity that allows not only for the internal development of individuals but also for a "smooth transition" from roles such as active professional worker to the role of the retiree.

An educational activity that can be described as one of the most popular and at the same time easily accessible for the elderly people is reading. In 2019, public libraries had over $15 \%$ share of elderly people among the total number of readers. This means that over 900,000 seniors use library services in Poland (the number of older people in 2019 in Poland was over 9.7 million). A comparative analysis of the National Library's readership polls shows however that among older people we still have the lowest percentage of readers. The educational activities of seniors also include the following activities: participation in artistic groups or membership in interest group workshops or classes which are most often run by community or cultural centers. In such places, the following classes are most often offered: dance, music, art and tech, theater, literary and IT. The number of elderly people using 
such forms of educational activity in 2019 amounted to a total of 210,406 people (which constitutes $36.6 \%$ of all participants). Therefore, it follows that in 2019 only $2.17 \%$ of older people used the above-mentioned educational opportunities available in Poland (Ministry of Family and Social Policy 2020).

The organisation of learning activities takes different forms and is aimed at seniors with different needs, but the goal of each of them is to make the elderly more functional and to encourage them to remain active, in addition to enabling them to make new relations or to raise their self-esteem as well as to have the opportunity to satisfy higher-level needs. „Today, no one questions the fact that elderly people can acquire new knowledge and skills. Learning is not only possible but even necessary to maintain intellectual capacity in old age" (Rudnik 2017, p. 117).

One of the most popular forms of education that meets the needs of older people in this area are the Universities of the Third Age that promote the idea of lifelong learning. They offer content and educational methods adapted to a cultural change, which contribute to effectively counteracting marginalisation and prepare for active participation in not only social or local but also cultural life. The obvious reason for the need for a UTA is the increase in the elderly population and, from a sociological perspective, continued active participation in the non-family and non-professional areas. UTAs usually function as associations, but in provincial capitals they are internal universitydepartments. In the report of the Statistics Poland it was noted that in 2018, 640 Universities of the Third Age were active. Most often, the educational offer of a UTA includes organising and conducting lectures, seminars, regular classes or workshops, courses and special interest clubs (Central Statistical Office 2019). The average attendance, nationally, of students' participation in regular classes was over $63 \%$ in 2018, while 9 units reported $100 \%$ attendance. Across all universities it was recorded that a total of 113.2 thousand of elderly people were studying. It is important to note that 95.4 thousand of students were women. The growing interest of elderly people in the activities of the UTA is connected with the wide range of courses offered, which, in addition to the abovementioned standard courses, include: language courses, art classes, computer classes and modern ICT classes, sports and exercise classes, as well as trips and visits to cinemas, theatres and museums (Central Statistical Office 2019). It is undeniable that Universities of the Third Age are the most recognisable form of learning for senior citizens. In recent years, a number of universities have been established in smaller towns, which has resulted in the fact that this form of educational activity is no longer associated only with a narrow group of people, mostly well-educated. At present, a wide range of not only educational, but also recreational, sporting and tourist activities encourages elderly people to participate in the programme (Fabiś i in. 2015) ${ }^{2}$.

2 The presented data from the report "Universities of the Third Age in Poland in 2018" of the Central Statistical Office are the most recently available data. 


\section{Purpose, method and research results}

The following part of the article presents the results of a study aimed at verifying students' opinions on various aspects of elderly people. The results of students' opinions on only one of the studied spheres of seniors' functioning are presented, i.e. the issue of elderly people's activity discussed in the article, which particularly concerns the area of education and acquiring new skills. The most important way of collecting material used to study this issue was the method of diagnostic survey, using the author's survey questionnaire. The questionnaire was anonymous and was conducted among the students of the higher education institution, i.e. Cardinal Stefan Wyszyński University in Warsaw at the Faculty of Social and Economic Sciences in the field of Social Work and at the Faculty of Pedagogical Sciences in the field of Pedagogy. 125 students took part in the survey, among whom there were both men and women, aged 18-45. The collected empirical material was subject to formal and substantive verification, and the collected data was presented in a descriptive form.

One of the main questions concerned students' opinions about the willingness of elderly people to learn new things. Activation practices of the elderly is possible only when both parties, the givers and the receivers, are committed to participate. In such activities, cooperation is only effective when there is a balance between seniors and organisers or instructors of the courses equally eager to collaborate. It was therefore interesting to observe the students' perceptions of this area of activity of the elderly group. The question was: „In your opinion, are elderly people willing to learn new things/acquire new skills?" It intentionally included two activities: learning new things, which could be interpreted as educational activities, and acquiring new skills, which could be associated with a group of creative activities such as yoga, sewing classes or chess. This question had a significant prevalence of ,no' answers. As many as 56 students (44.8\%) explicitly stated that the elderly group is not interested in getting involved in activating initiatives. It was also noticeable that there was a little difference in the ,yes' and ,I don't know' response options, with 36 respondents $(28.8 \%)$ remaining undecided on a clear answer and only 33 people (26.4\%) indicating that elderly people are keen to learn new things and want to acquire new skills.

One of the questions designed to investigate students' views on the desire for development by elderly people was „Do you think seniors actively participate in workshops organised by local institutions?”. In order to determine as accurately as possible the students' attitudes towards the phenomenon of seniors' education and their participation in organised activities, a 5-point Likert scale was used. The results were as follows: 28 students, representing $22.4 \%$ of the respondents, chose the answer "don't know" and the extreme answers: „definitely yes” and "definitely no" were selected by $2(1.6 \%)$ and $4(3.2 \%)$ people respectively. The ,rather not' option was chosen most often and accounted for $37.6 \%$ of the respondents. 44 respondents 
(35.2\%) had a positive perception of seniors' participation in workshops and meetings organised by municipal or city institutions. The cumulative percentage for ,definitely not' and ,rather not' was 40.8\%, while, definitely yes' and ,rather yes' accounted for $36.8 \%$ of responses.

The question aimed at determining what students believe elderly people do to spend their free time was as follows: „How do elderly people most often spend their free time in your opinion?". The range of answers included the 8 most popular activities, from which respondents could select any number of answers, as well as write down their own thoughts. The total number of responses was 375 , and on average each student ticked 3 options. Among the most frequently chosen answers, three were recorded, where each of them received more than 95 responses among students. The most frequently chosen activity that elderly people perform in their free time, according to the respondents, is watching TV. This activity received 100 indications, representing $26.7 \%$ of all selections. Very similar results were obtained for the options: caring for grandchildren and going to the church. The former was selected by 99 students which was $26.4 \%$ of the responses, while going to church was selected by 97 students, accounting for $25.9 \%$ of all chosen answers. Each of the other five options received less than 50 answers. 42 students chose the answer ,reading books', which was $11.2 \%$ of the responses and 20 students checked,work', which was $5.3 \%$ of the responses. The group of the least chosen options included: creative work, thematic workshops and further education. They obtained 8, 6 and 3 indications, respectively. The ninth response option included in the question was the category „Others (which?)”, it referred to individual associations, in which any number of activities could be written. The aforementioned category was included in the range of answers because the respondents may have had a different perception of elderly people than the author of the survey questionnaire, and thus also have different perceptions of elderly people's leisure activities. However, only 13 students chose this option, which constitutes $10.4 \%$ of the respondents. Among the answers in this category, the recorded activities most often had only one answer. The highest number of responses were gardening, which was recorded by 4 students, and membership in a senior club, which was indicated by 3 students. Some single responses were: cooking, caring for a pet, crossword puzzles, newspapers, making homemade preserves, sewing, tourist trips, sightseeing.

The presented responses indicate a specific direction of students' associations with leisure activities by the elderly. There is some kind of stereotypical approach in this particular area of seniors' lives. The answers provided by the respondents clearly show that to them the most frequent activities are connected with the role of a grandmother/grandfather and helping the family, with religiousness and spending time monotonously in front of the TV. Very few responses were related to the development of the elderly. The answers recorded by the author of the questionnaire, such as doing creative work, participating in thematic workshops or further education, were deliberately included among possible options directly 
linked to elderly people's ability to develop and learn new things. Unfortunately, there were the three (out of 8) least chosen options, which can be attributed to the prevailing "image” of the elderly in contemporary society, however not always entirely true.

\section{Conclusions}

Although human ageing is a highly individualised and multifaceted process, it has many consistent as well as repetitive aspects through which the images of elderly people are created, as well as definitions of ageing are formed. It is therefore important to realise, not only for young people but also for children and adults, that old age as this particular stage of life does not mean, stagnation' or giving up imaginative and creative ways of spending free time. It is characterized only by a decrease in internal and external activity, which is a natural situation in old age. Moreover, elderly people who are not at the same level of physical and mental functioning as in earlier years of their lives may need help or support in carrying out various activities, yet advanced age should not be a reason to give up these activities.

The study was exploratory and it was helpful to understand students' perspectives on elderly people. This was an intentionally selected research group, as it is the students who will soon be the group entering a period not only of professional activity, but most importantly, each of them will be functioning as an independent and autonomous individual in society. This particular group of young people can be the impetus for informed actions on behalf of seniors and thus improve their quality of life. The data on educational activities and leisure time activities clearly show the direction of students' associations concerning this area. Elderly people were judged to be reluctant to acquire new skills and learn new things. The willingness of seniors to participate in various forms of educational activation, such as thematic workshops or special interest clubs, was negatively judged. The survey shows that according to students, the most common activities are related to the role of grandmother/grandfather and helping the family, religiousness, and spending time in front of the TV. Few answers indicated doing creative work, further education or developing passions and hobbies. The data collected clearly show the repetition of generally accepted opinions that old age means the inhibition of various types of activity and „stagnation” in many areas of daily life.

Old age is not positively valued in the current culture of youth, as evidenced by the indications of psychologists, sociologists and educators. They indicate a negative attitude towards this age group, as evidenced by the functioning of such concepts in the literature as ageism (this phenomenon is most often referred to in the context of old age) or gerontophobia. Therefore, it is important to include the issues related to old age in the education process to a greater extent, both for young people and for lifelong learners. No less important will also be a deeper reflection on the image of the elderly in the media and the Internet. 
This analysis covers the current content related to the educational activity of elderly people, which is increasingly explored in scientific discussions. The content presented in the article can be used to consider the issue under discussion and, although it does not solve the issues concerning the group of elderly people and their development and functioning in society, it can be used to evaluate perceptions of elderly people's educational activities and to understand them more clearly.

\section{Bibliography}

Bąk A., Hołda M. (2013). Seniorzy w sieci. Między stereotypem a prawda. W: Człowiek zalogowany. Od mowy nienawiści do integracji w sieci. Wysocka-Pleczyk M., Świeży B. (red.). Kraków: Biblioteka Jagiellońska.

Bień B. (2002). Stan zdrowia i sprawność ludzi starszych. W: Polska starość. Synak B. (red.). Gdańsk: Wydawnictwo Uniwersytetu Gdańskiego.

Starzenie się i starość w perspektywie pracy socjalnej. (2014). Chabior A., Fabiś A., Wawrzyniak J.K. (red.). Warszawa: Centrum Rozwoju Zasobów Ludzkich.

Demetrio D. (2006). Edukacja dorostych. W: Pedagogika. Subdyscypliny wiedzy pedagogicznej. Śliwerski B. (red.). T. 3. Gdańsk: Gdańskie Wydawnictwo Psychologiczne.

Dubas E. (2010). Uczenie się przez przypadek jako przestrzeń edukacji dorostych. Perspektywa biograficzna. W: Uczacy się dorosty w zmieniającym się świecie. Fabiś A., Stopińska-Pająk A. (red.). Bielsko-Biała: Akademickie Towarzystwo Andragogiczne.

Dzięgielewska M. (2006). Aktywność społeczna i edukacyjna $w$ fazie starości. W: Podstawy gerontologii społecznej. Szatur-Jaworska B., Błędowski P., Dzięgielewska M. (red.). Warszawa: Oficyna Wydawnicza ASPRA-JR.

Dzięgielewska M. (2008). Edukacja osób starszych w codzienności. W: Edukacja do i w starości. Kuchcińska M. (red.). Bydgoszcz: Wydawnictwo KujawskoPomorskiej Szkoły Wyższej.

Ludzka starość. Wybrane zagadnienia gerontologii społecznej. (2015). Fabiś A., Wawrzyniak J. K., Chabior A. (red.). Kraków: Oficyna Wydawnicza „Impuls”.

Główny Urząd Statystyczny. (2020). Sytuacja osób starszych w Polsce w 2018 r. Warszawa-Białystok.

Główny Urząd Statystyczny. (2019). Uniwersytety trzeciego wieku w Polsce w 2018 r. Warszawa.

Halicki J. (2009). Edukacja w starości jako działanie poprawiające jakość życia seniorów. „Chowanna”, $\mathrm{nr} 2$ (33), s. 203-212.

Hebda J., Biela A. (2015). Znaczenie stereotypów i teorii starzenia się w postrzeganiu społecznym osób starszych. „Edukacja Etyczna”, nr 9, s. 49-62.

Kurcz I. (2001). Zmiana stereotypów: Jej mechanizmy i granice. W: Stereotypy i uprzedzenia. Uwarunkowania psychologiczne i kulturowe. Kofta M., Jasińska-Kania A. (red.). Warszawa: Wydawnictwo Naukowe Scholar. 
Leszczyńska-Rejchert A. (2006). Człowiek starszy i jego wspomaganie - wstronępedagogiki starości. Olsztyn: Wydawnictwo Uniwersytetu Warmińsko-Mazurskiego.

Leszczyńska-Rejchert A. (2019). Wbrew stereotypom - pomyślna starość „wyjątkowych" seniorów: studium z pedagogiki społecznej. Olsztyn: Wydawnictwo Uniwersytetu Warmińsko-Mazurskiego.

Łopatkowa M. (2005). Pedagogika serca wychowaniem dla pokoju. W: Ochrona dziecka. Teoria i praktyka. Hołtyst B. (red.). Legionowo: Centrum Szkolenia Policji.

Ministerstwo Rodziny i Polityki Społecznej. (2020). Informacja o sytuacji osób starszych $w$ Polsce za $2019 r$. Warszawa.

Miszczak E. (2010). Aktywność seniorów sposobem przeciwdziałania negatywnym skutkom procesu starzenia się. W: Jakość życia seniorów w XXI wieku: ku aktywności. Kałuża D., Szukalski P. (red.). Łódź: Wydawnictwo Biblioteka.

Nawrocka J. (2013). Społeczne doświadczenie starości. Stereotypy, postawy, wybory. Kraków: Oficyna Wydawnicza „Impuls”.

Orzechowska G. (1999). Aktualne problemy gerontologii społecznej. Olsztyn: Wyższa Szkoła Pedagogiczna w Olsztynie.

Piotrowski J. (1973). Miejsce człowieka starego w rodzinie i społeczeństwie. Warszawa: Państwowe Wydawnictwo Naukowe.

Rudnik A. (2017). Edukacja w starości - życzenie czy szansa na przeciwdziałanie marginalizacji osób starszych? „Pedagogika Społeczna”, nr 1 (63), s. 111-128.

Semków J. (2007). Andragogiczne uniwersalia - mit czy rzeczywistość? W: Uniwersalne problemy andragogiki i gerontologii. Dubas E. (red.). Łódź: Wydawnictwo Uniwersytetu Łódzkiego.

Steuden S. (2011). Psychologia starzenia się i starości. Warszawa: Wydawnictwo Naukowe PWN.

Szarota Z. (2002). Percepcja starości wśród studentów. „Rocznik Komisji Nauk Pedagogicznych", t. 55, s. 129-142.

Szarota Z. (2004). Gerontologia społeczna i oświatowa. Kraków: Wydawnictwo Naukowe Akademii Pedagogicznej.

Tomaszewska-Hołub B. (2019). Stereotypizacja starości - wybrane przejawy ageizmu. „Cywilizacja i Polityka”, t. 17 (17), s. 90-101.

Trafiałek E. (2006). Uniwersytety Trzeciego Wieku w zapobieganiu marginalizacji społecznej ludzi starych. „Gerontologia Społeczna”, nr 1, s. 19-25.

Ziółkowski P. (2017). Szkice z pedagogiki senioralnej. Bydgoszcz: Wydawnictwo Uczelniane Wyższej Szkoły Gospodarki. 


\title{
AKTYWNOŚĆ EDUKACYJNA SENIORÓW W POLSKIM PIŚMIENNICTWIE OSTATNICH LAT I W OPINII STUDENTÓW
}

\begin{abstract}
Streszczenie: Zjawisko starzenia się ludności jest istotne nie tylko ze względów ekonomicznych, gospodarczych czy demograficznych dla państwa, ale także społecznych. Szeroko pojęta pedagogika starości jest ważna dla rozwoju seniorów, oraz zmian w świadomości społeczeństwa, które zaczyna dostrzegać ogromne znaczenie, jakie ludzie starsi mają w państwie. Artykuł nawiązuje do kwestii aktywności edukacyjnej osób starszych oraz jej roli w poprawianiu jakości ich życia. Edukacja seniorów jest jedną z możliwości rozwoju współpracy między młodszymi grupami społeczeństwa a osobami starszymi. Dlatego też w artykule oprócz polskich pozycji piśmienniczych dotyczących aktywności osób starszych pojawią się także zgromadzone opinie studentów, które przedstawią rozważania współczesnego pokolenia dotyczące poruszanego zagadnienia.
\end{abstract}

Słowa kluczowe: starość, osoby starsze, aktywność osób starszych, aktywność edukacyjna seniorów, Uniwersytet Trzeciego Wieku. 